\title{
Lost and Found: The Value of a Little Known Bilingual Dictionary Towards the Intellectualization of Ndau*
}

\author{
Emmanuel Sithole, Rhodes University, Grahamstown, \\ South Africa (emmanesu@gmail.com) \\ and \\ Dion Nkomo, School of Languages, Rhodes University, Grahamstown, \\ South Africa (d.nkomo@ru.ac.za)
}

\begin{abstract}
This article critically evaluates the ChiNdau-English and English-ChiNdau Vocabulary: With Grammatical Notes, a bilingual dictionary published in 1915 by the American Board Mission (Rhodesian Branch), with a view of determining its suitability for use as a point of departure for modern Ndau lexicography. More than a century after its publication, it remains the only dictionary in the language. The language has been treated as a dialect of Shona for close to a century, until its emergence as one of the country's sixteen officially-recognized languages in the 2013 Constitution of Zimbabwe. This landmark development requires practical work that can transform Ndau into a fully-fledged and intellectualized language. Lexicography is one of the key intellectual enterprises that can contribute in this regard. It is therefore the contention of this article that the existing dictionary be considered as a vital point of reference for future lexicographic work in Ndau. An analysis of various aspects of the dictionary indicate that, notwithstanding some limitations, this dictionary indeed managed to set some standards that may be incorporated in current and future lexicographic works in this less documented language.
\end{abstract}

Keywords: DICTIONARIES, MISSIONARY LEXICOGRAPHY, CHINDAU, CHINDAU VOCABULARY, NDAU, NDAU LEXICOGRAPHY, NDAU ORTHOGRAPHY, LANGUAGE INTELLECTUALIZATION, MARGINALIZED LANGUAGES, OFFICIALLY-RECOGNIZED LANGUAGES, ZIMBABWEAN LEXICOGRAPHY

Opsomming: Verlore en gevind: Die waarde van 'n taamlik onbekende tweetalige woordeboek rakende die intellektualisering van Ndau. In hierdie artikel word die ChiNdau-English and English-ChiNdau Vocabulary: With Grammatical Notes, 'n tweetalige woordeboek wat in 1915 deur die American Board Mission se Rhodesiese tak gepubliseer is, krities beoordeel ten einde die toepaslikheid daarvan vir gebruik as 'n vertrekpunt vir die moderne

* This article was presented as a paper at the Twenty-first Annual International Conference of the African Association for Lexicography (AFRILEX), which was hosted by the Xitsonga and Sesotho sa Leboa National Lexicography Units, Tzaneen, South Africa, 4-6 July 2016. 
Ndau-leksikografie te bepaal. Meer as 'n eeu ná die publikasie daarvan is dit steeds die enigste woordeboek in die taal. Die taal is vir ongeveer ' $n$ honderd jaar behandel as ' $n$ dialek van Shona totdat dit in 2013 in die Grondwet van Zimbabwe as een van die land se sestien amptelik erkende tale verklaar is. Hierdie belangrike gebeurtenis vereis praktiese werk ten einde Ndau in 'n volledige en geïntellektualiseerde taal te omskep. Leksikografie is een van die deurslaggewende intellektuele ondernemings wat hiertoe kan bydra. Dit is dus die betoog van hierdie artikel dat die bestaande woordeboek beskou word as 'n onmisbare uitgangspunt vir toekomstige leksikografiese werk in Ndau. 'n Ontleding van verskeie aspekte van die woordeboek toon dat hierdie woordeboek ten spyte van sommige beperkings inderdaad daarin geslaag het om sekere standaarde te stel wat in huidige en toekomstige leksikografiese werke in hierdie minder gedokumenteerde taal ingesluit kan word.

Sleutelwoorde: WOORDEBOEKE, SENDINGLEKSIKOGRAFIE, CHINDAU, CHINDAUWOORDESKAT, NDAU, NDAU-LEKSIKOGRAFIE, NDAU-ORTOGRAFIE, TAALINTELLEKTUALISERING, GEMARGINALISEERDE TALE, AMPTELIK ERKENDE TALE, ZIMBABWIESE LEKSIKOGRAFIE

\section{Introduction}

Ndau is a language that straddles Zimbabwe's south-eastern districts and central Mozambique with a combined total population of almost 1, 6 million speakers (Instituto Nacional de Estatisco 2010; Zimbabwe National Statistics Agency 2012). It has five mutually intelligible varieties namely, Shanga and Danda, spoken in Mozambique, Garwe and Tonga, spoken exclusively in Zimbabwe, and Ndaundau/Ndau which straddles the arbitrarily drawn international border between the two countries (MacGonagle 2007). Despite constitutional recognition in both countries, the language is still patently marginalized as it is restricted to private and community domains where it mediates communication in interpersonal, religious and cultural domains. Despite the vital parent-to-child transmission of Ndau, the language confronts a genuine displacement risk by powerful contact languages like English, Shona and Portuguese which Ndau speakers now find convenient to adopt and use even in their home and community domains. The language remains under-described and underdocumented, with very little church literature that was published by missionaries between 1903 and 1928 (Sithole 2017). This article, therefore, seeks to offer a critical discussion of how the ChiNdau-English and English-ChiNdau Vocabulary: With Grammatical Notes, henceforth the Ndau Vocabulary, can be used as a basis for modern Ndau lexicography and the general intellectualization of Ndau.

The term intellectualization has a long history dating back to the Prague School of Linguistics in the 1930s where it referred to the development of language to "express the interrelationships and complexity of thought processes" (Havranek 1964: 6) of a linguistic community. In contemporary scholarship, the term has been given intellectual currency by Philippines scholars, who include Bonifacio Sibayan who defines "an intellectualized language as one that func- 
tions in the controlling domains of language" (Sibayan 1999: 229). Thus language intellectualization refers to the development and use of a language in high-status domains such as education, media, science, technology, and economy among others. In the context of Ndau, this necessitates urgent interventions to codify, elaborate and document it so that it can function in intellectual domains consistent with the constitutional stipulations in Zimbabwe.

Most of the earliest literature in African languages published by missionaries is now little known as the majority of mother-tongue speakers, researchers and academics have become oblivious of its existence. Accordingly, this article regards them as lost. For Ndau, some of the materials, such as the Ndau Vocabulary, were never disseminated widely while others were destroyed by fire alongside a printing plant at Chikore Mission in 1916. Only some few selected texts were re-published later (Doke 1931a: 132). For instance, the Ndau Vocabulary has been reproduced in microfilm format and is now available at a number of university libraries in South Africa. Thus the dictionary has been found and, together with other literary materials, needs to be re-examined in order to determine its contemporary relevance and potential use in current and future language intellectualization endeavours.

The history of the development of languages in general confirms the salience of old materials in providing a basis for language intellectualization. Old materials such as dictionaries are relevant and influential in the codification of marginalized languages such as Ndau. For illustration, Samuel Johnson's (1755) A Dictionary of the English Language was useful as a basis for the compilation of the Oxford English Dictionary (Nkomo 2017). It is thus reasonable for academics to subject such materials to critical scrutiny. For example, Gouws (2016) examines "a few lesser known Afrikaans dictionary monuments" (Gouws 2016: 355). In the same way, this article demonstrates that Ndau Vocabulary can effectively support scholarly efforts of documenting, preserving, maintaining and intellectualizing Ndau. A number of pertinent issues regarding the dictionary, such as orthography, lemmatization, definitions and lexical coverage are examined in order to get an insightful perspective for future lexicographic work in the language.

\section{Functions of dictionaries in marginalized languages}

To date lexicography as a discipline and practice boasts of a glorious historical timespan of over 4000 years with all sorts of dictionary typologies - normative, synchronic, diachronic, pedagogic, monolingual, bilingual and multilingual - being published in different forms over that longue durée. Both the socalled civilized and uncivilized worlds have continued to find the motivation to produce lexicographic products of diverse types because of the fundamental role of dictionaries in society, particularly their problem-solving function (Béjoint 2010; Hartmann 2001; Yong and Peng 2007). Dictionaries execute pertinent linguistic, communicative and cognitive roles in society. Yet even more 
compelling for marginalized languages is the language planning role played by dictionaries towards the emergence of national languages from European vernaculars together with the rise of modern European states during the Renaissance period (Mugglestone 2015; Nkomo 2017).

African languages are marginalized in higher order domains owing to colonial language policies. However, it is notable that a few languages like Swahili have morphed into powerful languages hogging the public domains in society - thanks to deliberate, strategic and timely political interventions by committed stakeholders. In this respect, the focus of this article narrows to marginalized languages, such as Ndau in Zimbabwe, that are still restricted to religious and cultural domains. They are in such a precarious position because of serious challenges involving, but not limited to, assimilation into dominant languages, widespread antipathy against their use in key domains as well as the absence of appropriate materials to facilitate their use in such influential domains. To reverse this situation, this article maintains the scholarly view that dictionaries play a pivotal role in language development (Landau 2001; Hadebe 2006). Dictionaries are important in setting a basis for language codification, language standardization, language planning, language documentation and language resuscitation.

For a marginalized language like Ndau, print dictionaries, online dictionaries, computer dictionaries and cellphone dictionaries are critical for its revitalization, growth and intellectualization. In an uncodified and unstandardized language, earlier lexicographic works can inform better documentation and standardization because their data could be reutilized for many other language-related activities including literacy, grammar, literature and linguistic description. Appropriate and informed use of dictionaries helps in mediating communication between various stakeholders in public domains. That way, dictionaries can meaningfully facilitate the acquisition and dissemination of information and knowledge, thereby satisfying current and future needs of users. From that perspective, it is hoped that lexicography can assist in transforming the status of Ndau into a functional language that executes utilitarian and cognitive functions in education, media, technology, administration, legislature and the judiciary.

\section{The Ndau Vocabulary}

It is not very clear who compiled and edited the Ndau Vocabulary. Several versions of the dictionary in existence bear different names of missionaries who worked in the Ndau speaking communities in Zimbabwe and Mozambique. Among these missionaries are J.P. Dysart, G.A. Wilder and A.J. Orner. For example, there is a version that is attributed to Wilder, another one that is credited to Dysart and Orner, and another version that simply bears the name of the publisher, the American Board Mission. Two things that are certain are that the dictionary was published by the American Board Mission at Mt. 
Selinda, Zimbabwe, and that it was published in 1915, since those details appear consistently in all the versions. Although the content of the dictionary is the same, this article is based on the version attributed to J.P. Dysart and A.J. Orner. Its compilation had an external motivation (Gouws 2005) of serving "new missionaries, civil servants and other white residents of the country" (Dysart and Orner 1915: 4). It was intended to "be of real service to those who may use it in the evangelization and civilization of the Ndau people" (Dysart and Orner 1915: 4). That way, it would serve both pedagogical and communicative functions. In line with this purpose, the dictionary provides some brief notes on Ndau grammar, as clearly expressed in its title. The remainder of the article discusses the salient features of the dictionary in order to assess its contribution towards the codification and standardization of Ndau. The discussion will focus on the lexical coverage, data presentation, lemmatization, definitions and orthographic choices made in the dictionary. Such a discussion hopes to inform lexicographic discussions around the compilation of future dictionaries not only in Ndau but also in other marginalized languages.

\subsection{Lexical coverage}

The Ndau Vocabulary has 4000 lemmas across two alphabetical sections. It follows the traditional Aa-to-Zz listing approach with the Chindau-English section occupying $45.3 \%$ (63 pages) while the English-Chindau section takes up $39.5 \%$ (55 pages). The front matter which comprises of the preface and grammatical notes has $13.7 \%$ (19 pages) while the back matter which includes names of birds, fish and trees has only $0.7 \%$ (1 page). The 4000 wordlist in the dictionary is not only a good starting point for future lexicographic endeavors but also for linguistic and sociolinguistic purposes. Lexicographers could use the wordlist to guide the compilation of future monolingual and bilingual dictionaries while linguists and sociolinguists could use it as a basis for the study of linguistic notions such as phonology, semantics, lexical variation and language change, given the paucity of texts in the language.

As a cross border language, entries for the dictionary were drawn from the five dialects of Ndau already identified above. Entries from the five different dialects were labelled using either the shortened forms of the dialect, for example, Chid for Chiduma (Tonga), or the abbreviations for the place where the dialect is spoken, for example, L.B for Lower Buzi (Shanga) (Dysart and Orner 1915: 20). The inclusion of vocabulary from the different dialects captures the heterogeneous nature of Ndau. In future Ndau lexicography, dialect labeling as done in the Ndau Vocabulary should be maintained not only for showing the dialect scenario in the language but also towards contributing to the overall intellectualization agenda of Ndau. It would also avoid criticism and rejection problems akin to Duramazwi ReChiShona, the monolingual Shona dictionary, which some reviewers and users vowed not to use, insisting that it was biased towards Karanga, the mother-tongue of the editor-in-chief (Chimhundu 2010: 110). 
The dictionary also accommodated a significant amount of borrowings from contact languages such as English, Afrikaans, Portuguese and Shona. Despite being a general-purpose dictionary with an overly Christian inclination, the dictionary also covers vocabulary from other important domains of society. In view of that, the dictionary strives to maintain a fair lexical balance by including data from diverse primary and secondary sectors. Such a positive attribute can be used as a stepping stone towards developing future monolingual and bilingual dictionaries in the language which generally describe the language as it is used across all major domains (Zgusta 1971). While the compilers acknowledge the presence of inconsistencies, "faults, errors and incompleteness" (Dysart and Orner 1915: 3) on lemma selection and the overall dictionary contents, it is proffered that the Ndau Vocabulary can be very useful towards providing a foundation for the compilation of future dictionaries. It sets a norm or a standard upon which Ndau can be described for linguistic purposes. The dictionary can also be employed as a point of reference for further studies on Ndau vocabulary, grammar, terminology and lexicography. These activities assist towards corpus planning which is necessary for the intellectualization of the language.

\subsection{Presentation of data}

This section is a critical examination of both the macrostructural and microstructural aspects of the Ndau Vocabulary. It discusses how the compilers handled lexicographic aspects such as orthography, lemmatization, definitions, and grammar to establish how they can assist in developing Ndau. Such aspects are essential as they determine the extent to which dictionaries meet user needs. Largely, such aspects interlink with the size, volume and entire structure of the dictionary. It is therefore imperative to make a critical engagement with such aspects to identify how they can inform future lexicographic activities in Ndau. From a practical point of view, such issues are important as they help towards the standardization of the language as users often consult dictionaries to learn how to spell, pronounce and use words correctly (Hadebe 2006; Chimhundu 2010). It is therefore argued that the indicated aspects can determine the overall accessibility, acceptability and use of any dictionary compiled to meet communicative and cognitive needs of speakers in a society.

\subsubsection{Orthographic issues}

The compilers of the Ndau Vocabulary deserve commendation for devising a spelling system that adheres to the orthographic principle of accuracy. According to Capo (2002: 21) accuracy is a scientific orthography development practice where there is a one-to-one correspondence between sound and symbol. Lexicographers who compiled the dictionary used this principle to represent salient phonological aspects of Ndau such as aspiration, laterality and phonotactics. 
As Doke (1931b: 147) emphasizes, aspiration is an outstanding and widespread feature that deserves to be represented in Ndau. The compilers represented aspirated voiceless stops $<\mathrm{t}^{\mathrm{h}}, \mathrm{p}^{\mathrm{h}}>$ as in pumpha (make a false allegation) and nthekwe (snuff box) and laterality with $<$ hl $>$ as in huhlu (giraffe). Regrettably, the compilers were not consistent as observed in lemmas like kumucha (translate), mukeyo (drinking pot), kebe (melon) being lemmatized instead of khumucha, mukheyo and khebe. The compilers also distinguished the voiced labialized alveolar fricative $\langle\mathrm{zv}>$ with the voiced alveolar fricative $\langle\mathrm{z}>$ as in zina (name) and zina (dance) respectively while also using $<\mathrm{v}>$ to represent the voiced dentilabial fricative $\langle\mathrm{vh}\rangle$ and $\langle v\rangle$ voiced labiodental fricative $\langle\mathrm{v}\rangle$ as in vanga (scratch hard) and vangeri (gospel).

However, after Doke's (1931a) designation of Ndau as a dialect of Shona, some of its peculiar features such as clicks, laterals, aspiration were sacrificed. Interestingly, Doke's landmark one-sound-one symbol principle that resulted in special symbols borrowed from the International Phonetic Alphabet (IPA) was later abandoned and replaced in successive revisions. From this perspective, it can be argued that the Ndau Vocabulary laid a scientific foundation in orthography development which, when improved, can greatly assist towards the intellectualization of the language in functional domains. Its accurate symbols on aspiration, laterality and phonotactics among others can be incorporated in new revisions of Ndau orthography to fully match Ndau sounds to adopted symbols.

\subsubsection{Lemmatization}

The Ndau Vocabulary adopts a full word-lemmatization approach in the Aa-to$\mathbf{Z z}$ list. Full words are entered as the canonical forms of headwords without removing prefixes or extensions. This includes all word categories such as nouns, verbs, adverbs, interjections and prepositions. Only adjectives are lemmatized using the stem-based approach. Below is an examination and exemplification of how different speech categories are entered in the dictionary.

\subsubsection{Lemmatization of nouns}

The word lemmatization approach resulted in nouns being written directly as they are spoken. The initial letters of headwords were used to decide the alphabetical listing of nouns. The following is a description of how nouns are presented:

- The regular plural prefix is given after the noun, for example, besha, ma, cold in head.

- When the prefix is not used with the noun as in ' $\mathrm{i}-/$ dzi-' class, the plural pronoun is given in parentheses as in $\mathbf{m b u d z i},(\mathrm{dzi})$, goat. 
- Where the plural form is irregular the singular pronoun is given in parentheses followed by the plural noun with its pronoun in parenthesis as in rukuni, (ru), (Plur. huni-dzi), stick of fire-wood.

- Where a noun occurs in the singular or plural form only, it is followed by its pronoun and indicated as in nyama, (I sing. only), meat.

- Nouns of the ' $u$ ' and ' $k u$ ' classes, which have one form only, are followed by the pronoun in parenthesis as in uchi, (hu) honey; kurgya, $(\mathrm{ku})$, food.

- Nouns of the 'mu-/mi-' class beginning with ' $m w$ ' are followed by both the singular and plural pronouns when used in both singular and plural as in mwoyo, $(\mathrm{u}, \mathrm{i})$, heart.

- Where letters in nouns of the 'ri-/ma-' class change in the plural they are given in parenthesis as in banga, ma (p), knife (Dysart and Orner 1915: 19).

A critical look into how nouns are presented reveals that the compilers mixed different strategies in the lemmatization of nouns. The compilers used the full word lemmatization approach by entering singular nouns only as headwords. As singularity and plurality in Ndau is mostly indicated through prefixes, the lemmatization of singular noun headwords accompanied by their regular plural form prefixes became a space- and time-saving lexicographic technique that avoided lexical redundancy in the dictionary. It also links singular and plural nouns, for example, besha (cold in head) and mabesha (mucus) to grasp singularity and plurality rules in Ndau. But for purposes of future lexicographic endeavours in Ndau, it could be necessary to improve the lemmatization of nouns to make it more consistent. For instance, the description of bare (salt-pan) as exclusively a singular noun is misleading because there is mapare (salt-pans). It is evident that lemmas such as benzi (fool) and dahwa (night hawk) change into mapenzi (fools) and matahwa (night hawks) respectively when they are pluralized and not *madahwa and *mabenzi (which are grammatically incorrect) as implied in the morphophonemic rules governing the 'ri-/ma-' nouns.

The full word lemmatization approach used in the dictionary is usually the standard approach in agglutinating languages such as Ndau where conjunctive writing is usually preferred. This approach provides an easy and straightforward access to the lemma because it is given the full nominal form. Users do not encounter challenges of looking up the stem which in some cases like in class $9 / 10$ is evidently elusive. It is also easy to provide the category of the lemmas while also reassuring users that they are dealing with the correct lemma unlike using the stem lemmatization approach (Prinsloo 2011: 183-184).

\subsubsection{Lemmatization of verbs}

The Ndau Vocabulary consistently uses the full word lemmatization in verbs. In the quest to indicate grammatical information, it indicates 'v,' for 'verb', and 
'adv.,' 'adj.,' 'prep.,' 'conj.,' and 'interj.,' representing 'adverb,' 'adjective,' 'preposition,' 'conjunction,' and 'interjection' respectively as shown below.

dai, v., be like this.

, conj., as; if.

, verbal part. Indicates "let" as in-Ex. dai ndiende.

, ma $(\mathrm{t})$, branch of tree.

The adopted labeling style performs a key role of distinguishing different senses and categories of words. The lemma above has different categories and multiple meanings. Depending on the context, the lemma dai is used as a verb, verbal particle, conjunction and also as a noun which in its plural form is matai (branches). This clarifies the different senses in which the word is used. Despite its advantages, a word-based approach to the lemmatization of verbs is not feasible in a paper dictionary because verb stems can combine with numerous extensions. Unlike in English, agglutinating African languages like Ndau's verbs acquire prefixes, concords and extensions, which pose serious challenges in lemmatizing them. Some disadvantages of full word lemmatization in the Ndau Vocabulary are shown in examples below:

amba, v., begin; attack.

ambana, v., quarrel.

ambira, v., offend.

kuambana, $(\mathrm{ku})$, quarrel.

In relation to verbs, the word lemmatization approach encourages repetition; promotes the scattering of related words; and wastes space unnecessarily. It is doubtless that the alphabetization of verbs using their accompanying prefixes does not only physically separate verbs but also differentiates them with nominal derivatives such as (ku)ambana among others. In addition to that, adopting this approach promoted the reduplication of similar words in the Ndau Vocabulary as seen in Table 1 below:

Table 1: Lexical redundancy in the Ndau Vocabulary

\begin{tabular}{|l|l|l|l|}
\hline Verb lemma & Gloss & Verb/noun lemma & Gloss \\
\hline Buda & come out, go out & kubuda & projection \\
\hline Chengedza & deceive & kuchengedza & deceit \\
\hline Dakara & be happy & kudakara & happiness \\
\hline Dai & be & kudai & as, even, so, like \\
\hline Edza & tempt & kuedzwa & temptation \\
\hline Gwimba & groan & kugwimba & groan \\
\hline Irikidza & praise & kuirikidza & praise \\
\hline Jeka & shine, light & kujeka & light \\
\hline Angarara & be naughty & kuangarara & naughtiness \\
\hline
\end{tabular}


Table 1 shows the nominalization of verbs by prefixing them with the class 15 $(\mathrm{ku}-)$, but there is an interrelatedness between the meanings of verbs and nouns. This concurs with Prinsloo's (2011: 184) submission that at times nominal and verbal meanings are closely related which causes classification problems. These double, triple or quadruple entries in the Ndau Vocabulary redundantly increased the total number of headwords. Adopting the stem lemmatization strategy could have reduced the number of lemmas by grouping verbs and their related senses under one stem as this is a modern and economical lexicographic practice (De Schryver and Wilkes 2008). For example, amba, ambana, ambira could have entered under amba. This could also have effectively addressed the challenge posed by verbal and nominal words, for example, nominal derivatives such as kuambana could have been lemmatized alphabetically as full words under ku-.

\subsubsection{Lemmatization of adjectives}

Adjectives were lemmatized according to their stems. This is seen in doko (small), dodori (little, small amount), tsvuku (red), chena (white), svipu (black), rebu (tall, long) and refu (long, tall, high). Stem lemmatization is clearly a good lexicographic practice that saves time and space while also avoiding repetition. The compilers also managed to respond to dialectal variation by including dialectal variants for example, refu (Shanga) vs rebu (Ndaundau/Ndau); doko (Tonga, Garwe, Shanga) vs dodori (Danda, Ndaundau/ Ndau) as headwords. While the inclusion of variants as headwords was sociolinguistically and linguistically sound, it is, however, lexicographically less helpful as such lemmas are semantically similar. Apart from representing their individual dialects and the obtaining phonological differences, there is no useful information on them. This results in unnecessary repetition and redundancy, for example, rebu, adj., long; tall; high and refu, adj., long; tall; high.

While the decision to represent dialectal variation in the dictionary is sociolinguistically laudable, it is important that future lexicographers need to be careful not to include simple variants such as refu and rebu shown above. The two headwords are essentially allophones of the same word differing phonologically and dialectically. In modern lexicographic practice they could and should be entered as one word as they are lexically or semantically similar. It would suffice to use synonyms, for example, mbishi (Shanga) and gan'a (Ndaundau/Ndau) as headwords since they are lexically different. This is advantageous as it depicts the breadth and richness of Ndau's vocabulary.

\subsubsection{Lemmatization of loanwords}

In an attempt to describe Ndau as it was spoken, borrowed words were also lemmatized. This is in keeping with the lexicographic principle that dictionaries should be descriptive to document and express the current language as it is 
spoken. The majority of loanwords are rephonologised to reflect native Ndau speakers' pronunciation. The labels (Z) for Zulu, (E) for English, (D) for (Dutch), (Mash.) for Mashonaland, and (P) for Portuguese show the place or language from which the lemma is borrowed. Examples below show the loanwords in the dictionary as well as the languages from which they were borrowed:

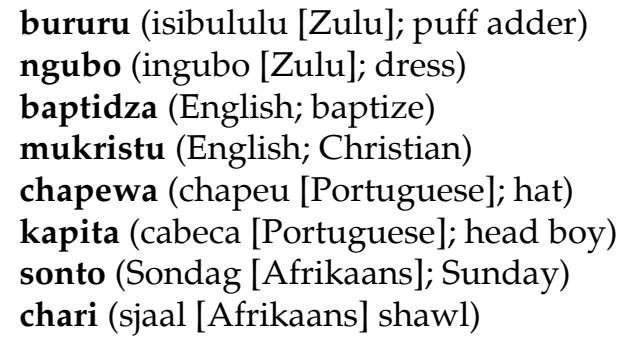

The compilers of the Ndau Vocabulary deserve commendation for handling loanwords in the dictionary considering that they are normally a problem in lexicography (Hadebe 2006). Naturally, words from other languages such as English and Portuguese do not conform to the orthographic and phonological conventions of Ndau. For instance, lemmas such as sonto, kristu, and baptidza exemplified above usher in new phonetic, phonological, morphological and semantic elements into the receptor language. However, elements such as "nt, $\mathrm{kr}$, st, pt and pr" frustrate the phonological rules of the language necessitating their separation by vowels, as in khirisitu and bhabhatidza and so on. However, the compilers failed to insert vowels to conform to the Ndau spelling system.

Sociolinguistically, the inclusion of loanwords concurs with Kwamangamalu's (1997: 89) observation that no language is lexically self-sufficient as languages always supplement their vocabularies with loanwords from other languages. This means that Ndau lexicon can easily grow through adopting and adapting words from contact languages. Examples of adoptives found in the dictionary include chibuko (mirror), jaha (boy) from Zulu; chapewa (hat) from Portuguese; chiamburera (umbrella), ginandera (granadilla) from English, puraze (prazero), tafura (table) from the then Dutch (now Afrikaans) and nyakwaa (smooth) from Shona. Labelling the source of borrowed words is critical in establishing a lexicographic foundation for treating loanwords in future Ndau dictionaries.

The inclusion of loanwords in the Ndau Vocabulary highlights sociolinguistic and diglossic situations in which Ndau exists. For example, words originally from ex-colonial languages demonstrate language power politics where Ndau is a subordinate language to English, Portuguese and Dutch as its speakers often borrow from them for prestige reasons. In the same vein, words borrowed from African languages such as Shona and Zulu expose the contemporary and historical contact scenario with Ndau. For instance, Ndau has a lin- 
guistic relationship with Shona. Also, the inclusion of lexical items of Nguni origin points to a historical and linguistic connection between Zulu and Ndau. Among other historians, MacGonagle (2007) states that Soshangane's GazaNguni group which was fleeing the Mfecane wars conquered the Ndau during the 1820s. The military, political, social and cultural contact, including intermarriages, between the original Ndau group and Soshangane's people resulted in a permanent accommodation of over 2000 Nguni lexical items in Ndau (Doke 1931a; Fortune 1990).

\subsubsection{Definitions}

Most traditional bilingual dictionaries by missionaries in Zimbabwe were normally translations of lemmata in both languages (Mpofu-Hamadziripi et al. 2013). An example is Hannan's (1979) Standard Shona Dictionary. The Ndau Vocabulary is in the same category implying that Ndau-English section headwords are translated into English while the reverse is also true. Apart from being mere translations, the dictionary has neither real definitions, nor contextual information nor synonyms of entries. In keeping with the dictionary's purpose, the compilers managed to provide reasonably adequate equivalences between the two languages.

The Ndau Vocabulary provides equivalences (which are treated as definitions in this article) that largely conform to the defining principles of cultural acceptability, accessibility and user-friendliness. Firstly, translators-cum-definers were careful in using non-technical language, which made word meanings easily accessible to learners in a general dictionary. Secondly, the compilers attempted to depict cultural and religious tolerance and resisted Eurocentric biases typical in literature published during the colonial period. For example, traditional religious terms such as mudzimu (personal ancestral spirit), n'anga (doctor), hakata (lots, bones for divining), chiremba (doctor skillful with hakata) could have been referred to as elements of either heathenism or paganism or both as in other early dictionaries in African languages. Such tendencies have been noted in other dictionaries that are products of missionary lexicography in Africa (Moropa and Kruger 2000). This makes the Ndau Vocabulary a relevant and socio-culturally acceptable lexicographic work even among contemporary mother-tongue users. Thirdly, the equivalences were not circumlocutive but very concise which made the dictionary easily express meanings to intended users. This satisfied the principle of brevity, which encourages straightforward definitions and translations.

\subsubsection{Grammatical information}

As an underdescribed language, there are no grammatical works in Ndau, which makes the Ndau Vocabulary the only reference thus far. While the compilers advise that "the grammatical notes are not intended to be complete or 
take the place of a grammar" (Dysart and Orner 1915: 3), the dictionary provides essential grammatical information that helps non-mother tongue speakers of Ndau to learn the language. It explains the morphophonemic rules governing the description and classification of nouns, pronouns, adjectives, verbs, verb phrases and inflections. For instance, it shows the rules determining the singularity/plurality of nouns in the (ri-/ma-) class, such as banga, ma (p), knife and (mu-/mi-) class like munda, $(\mathrm{mi})$ field as well the concordance rules governing the language. This helps in showing existing word and lexical relationships in the language as it is shown in the dictionary.

While the importance and effectiveness of such an incomplete Ndau grammar to non-mother tongue learners of Ndau could be tremendously questionable as there is a whole inconclusive debate relating to whether or not grammatical knowledge is necessary for foreign language learning, it is nevertheless very important to the standardization of the language. Acquiring the knowledge of grammar is critical to establish a basis upon which rules for writing, reading and mastering Ndau can be standardized. From the perspective of Ndau's intellectualization, it is important to emphasize that grammatical information is essential. This means that improving grammatical rules contained in the dictionary is critical towards informing further linguistic studies on Ndau.

\subsection{Ndau lexicography and the road ahead}

The way ahead for Ndau lexicography requires careful planning to produce a variety of dictionaries that serve as utility products and contribute towards the intellectualization of the language. Building on the century old, little known or lost and found dictionary, scholars and lexicographers, particularly mothertongue lexicographers, should design sound strategies and plans for the development of future dictionaries. Positive gains on orthography development; dialect unification and representation; cultural, religious and gender sensitivity; grammar; and phonology should be built on as explained in foregoing sections. Such strides should help create a foundation upon which future documentation of Ndau can be premised. This is more particularly advantageous in lexicography where a starting point has already been established.

The planning of future mono-/bi/-multilingual, specialized, general and pedagogical dictionaries in the language can meaningfully begin by using the Ndau Vocabulary as the basis. Researchers can begin by studying the 4000 headwords in the dictionary to establish whether they are still in use before collecting new words and defining them appropriately, taking cognisance of contemporary contexts.

Furthermore, data in the general-purpose dictionary can be converted to serve a specialized pedagogical function. This means that a children's dictionary can be built from a quantitative reduction of the words in the current dictionary. The basic vocabulary list from the dictionary can be selected, described 
and explained in a simple language consistent with children's level of linguistic competence. In a children's dictionary where language instruction for communication purposes is pursued it might be desirable to improve the data presentation approach. This can be very useful in concentrating essential information that can be constructively used for educational purposes. This is so despite the fact that scholars such as Hernandez (1989: 152) insist that reducing the size of a dictionary is a deplorable practice in the modern world of school dictionaries. Tarp (2011: 224) also echoes this view when he intones that "when a dictionary is the result of a purely quantitative reduction, it can no way be considered a work conceived for users." This is correct, taking into account that, for example, the original target users of the dictionary and native Ndau children's linguistic needs are different. However, it can still be possible and necessary with proper planning to adapt and produce a dictionary whose contents accurately address its user needs. For example, the reduction of old lemmas in the Ndau Vocabulary can be complemented by adding new vocabulary collected from every day communicative situations and define them appropriately to identify with children's communicative and cognitive needs. In that way, a new children's dictionary would be an improved lexicographic work, which would have used Ndau Vocabulary as a basis.

In view of the foregoing, it is important that the development of Ndau lexicography should assist immensely in the intellectualization of the language in Zimbabwe. Nkomo (2012: 223) is critical of the comprehensive lexicographic processes in Zimbabwe for their exclusive focus on Shona and Ndebele. He proposes a well-conceived comprehensive lexicographic process for Zimbabwean lexicography that also includes English as well as minority languages that were already gaining traction in education using successive language-in-education policies. In that case, an appropriate lexicographic intervention process is imperative in all the 16 officially-recognized languages with specific focus on minority languages such as Ndau. The constitutional recognition of previous minority languages to have official parity with majority languages such as Shona and Ndebele emphasizes the necessity of a paradigm shift to embrace multilingualism in the country by technically developing all the languages to function in important high-status domains. This bestows relevance on the crafting a comprehensive language policy whose tenets and stipulations are mirrored and implemented through an appropriate lexicographic intervention process in Zimbabwe. Taken together, this implies that the time is ripe to not only take stock and a critical evaluation of existing dictionaries such as the Ndau Vocabulary but to also think carefully about specific dictionary projects in the concerned languages.

\subsection{Conclusion}

Over a century ago, the compilers of the Ndau Vocabulary made it clear that the dictionary was never intended to be a complete or final grammatical or lexico- 
graphic work for the language. Instead, they acknowledged its 'incompleteness in the lists of words', definitions and other errors (Dysart and Orner 1915: 4) which need proper and careful attention in future lexicographic publications. Most importantly, they were cognizant of their own shortcomings but undertook to compile a work which would "serve as a basis for comparison" with other works in other Bantu languages "by those who were competent to make such a study." Such awareness indicates that the compilers never intended to forestall and preclude future and deeper studies in Ndau alone or as part of the larger Bantu language family. Instead, they encouraged further studies in Ndau by encouraging constructive criticism in the "spirit that seeks to improve the work already done" (Dysart and Orner 1915: 4). In tandem with such a selfless and visionary exhortation, this article focuses on how the Ndau Vocabulary could help create a foundation for future linguistic and lexicographical debates and practices. The dictionary can inform language documentation in the form of lexicography, terminology, grammar, linguistic comparison and language development. This makes it strategically positioned to support and champion the intellectualization of Ndau from a restricted community language to a vehicular language functioning in high-status domains. With Ndau now being one of the officially-recognized languages of Zimbabwe, there has not been a better time to build on the century old dictionary towards the intellectualization of the language.

\section{References}

Béjoint, H. 2010. The Lexicography of English. Oxford: Oxford University Press.

Capo, H.B.C. 2002. The Pan-dialectal Approach to Orthographic Conventions: The Case of the Gbe Languages of West Africa. Prah, K.K. (Ed.). 2002. Writing African: The Harmonization of Orthographic Conventions in African Languages: 5-25. Cape Town: The Centre for Advanced Studies in African Society (CASAS).

Chimhundu, H. 2010. Harmonization and the Handling of Language Variation in Shona. Lexicography. Chimhundu, H., W. Magwa and A. Chebanne (Eds.). 2010. Harmonization of ShonaNyai varieties: 105-122. Cape Town: CASAS.

De Schryver, G.-M. and A. Wilkes. 2008. User-friendly Dictionaries for Zulu: An Exercise in Complexicography. Bernal, E. and J. DeCesaris (Eds.). 2008. Proceedings of the XIII EURALEX International Congress, Barcelona, 15-19 July 2008: 827-836. Sèrie Activitats 20. Barcelona: Universitat Pompeu Fabra, Institut Universitari de Lingüística Aplicada.

Doke, C.M. 1931a. Report on the Unification of the Shona Dialects Carried Out under the Auspices of the Government of Southern Rhodesia and the Carnegie Corporation. Hertford: Stephen Austin and Sons.

Doke, C.M. 1931b. A Comparative Study in Shona Phonetics. Johannesburg: University of Witwatersrand Press.

Dysart, J.P. and A.J. Orner. 1915. ChiNdau-English English-ChiNdau Vocabulary: With Grammatical Notes. Mt. Selinda: American Board Mission, Rhodesian Branch.

Fortune, G. 1990. From Zulu to Ndau: A Change of Medium. South African Journal of African Languages 10(4): 354-364. 
Gouws, R.H. 2005. Lexicography in Africa. Brown, K. (Ed.). 2005. Encyclopedia of Language and Linguistics: 95-101. Second edition. Oxford: Elsevier.

Gouws, R.H. 2016. Enkele minder bekende Afrikaanse woordeboek-monumente. Tydskrif vir Geesteswetenskappe 56(2-1): 355-370.

Hadebe, S. 2006. The Standardisation of the Ndebele Language through Dictionary-making. Harare/ Oslo: The ALLEX Project.

Hannan, M. 1979. Standard Shona Dictionary. Second edition - Reprint with Addendum. Harare: College Press.

Hartmann, R.R.K. 2001. Teaching and Researching Lexicography. Essex: Pearson Education.

Havranek, B. 1964. The Functional Differentiation of the Standard Language. Garvin, P. (Ed.). 1964. A Prague School Reader on Esthetics, Literary Structure and Style: 3-16. Washington DC: Georgetown University Press.

Hernández, H. 1989. Los diccionarios de orientación escolar. Contribución al estudio de la lexicografía monolingüe española. Tübingen: Max Niemeyer.

Johnson, S. 1755. A Dictionary of the English Language. London: J. \& P. Knapton/T. \& T. Longman et al.

Kwamangamalu, N.M. 1997. Language Frontiers, Language Standardization, and Mother Tongue Education: The Zaire-Zambia Border Area with Reference to the Bemba Cluster. South African Journal of African Languages 17(3): 88-94.

Landau, S.I. 2001. Dictionaries: The Art and Craft of Lexicography. Second Edition. New York/Cambridge: Cambridge University Press.

MacGonagle, E. 2007. Crafting Identity in Zimbabwe and Mozambique. Rochester: University of Rochester Press.

Moropa, K. and A. Kruger. 2000. Mistranslation of Culture-specific Terms in Kropf's Kaffir-English Dictionary. South African Journal of Languages 20(1): 70-79.

Mpofu-Hamadziripi, N., A. Ngunga, E.N. Mberi and F. Matambirofa. 2013. A Descriptive Grammar of Shona. Harare: Sable Press.

Mugglestone, L. 2015. Samuel Johnson and the Journey into Words. Oxford: Oxford University Press.

Nkomo, D. 2012. Towards a Lexicographical Intervention in the Acquisition and Use of English in Zimbabwe. Unpublished D.Litt. Dissertation. Stellenbosch: Stellenbosch University.

Nkomo, D. 2017. Dictionaries and Language Policy. Fuertes-Olivera, P.A. (Ed.). 2017. The Routledge Handbook of Lexicography: 152-165. London: Routledge.

Prinsloo, D.J. 2011. A Critical Analysis of the Lemmatisation of Nouns and Verbs in IsiZulu. Lexikos 21: 169-193.

Sibayan, B.P. 1999. The Intellectualization of Filipino. International Journal of the Sociology of Language 88(1): 69-82.

Sithole, E. 2017. From Dialect to 'Official' Language: Towards the Intellectualization of Ndau in Zimbabwe. Unpublished D.Phil. Thesis. Grahamstown: Rhodes University.

Tarp, S. 2011. Pedagogical Lexicography: Towards a New and Strict Typology Corresponding to the Present State-of-the-Art. Lexikos 21: 217-231.

Yong, H. and J. Peng. 2007. Bilingual Lexicography from a Communicative Perspective. Amsterdam/ Philadelphia: John Benjamins.

Zgusta, L. 1971. Manual of Lexicography. The Hague: Mouton. 